\title{
社会資本整備における官民パートナーシップのための制度設計 *
}

Institutional Design of Public-Private Partnerships for Infrastructure Projects*

大西正光**. 石磊***

by Masamitsu ONISHI**, Lei SHI***

\section{1.はじめに}

どの国でも，公共サービスの調達は一国の経済活 動において大きな割合を占めており，いかに低コス トで質の高いサービスを国民に提供できるかは重要 な課題である．このような公共サービス調達の効率 性向上を目的として, 公共主体と民間企業との間の 新しい関わり方が模索されている. すなわち, 官民パ ートナーシップ (Public-Private Partnership, 以下 PPP）と呼ばれる契約形態により公共主体が民間企 業とともに, 社会資本整備を行い, 運営管理まで一貫 して実施するという手法が世界的潮流で多く実践さ れてつつある．わが国においても，1999年に民間資 金等の活用による公共施設等の整備等の促進に関す る法律 (いわゆる PFI法) が成立して以来, インフラ 関係ではまだ実施例がないものの，いわゆるハコモ ノ関連では，わが国においても着実にその適用事例 が増加しつつある. PFI (Private Finance Intiative) とは，民間セクターがその資金とノウハウを活用し つつ設計, 建設, 維持管理, 運営までを一体として 行いながら公共サービスを供給する民営化手法であ $ろ^{1)-4)}$.

公共主体に善意がある（benevolent）ことを前提 とすれば, 公共主体の意思決定者はPPP という契約 形態が伝統的な契約形態と比較して, 社会的観点か ら望ましいという前提に基づきPPPを適用してい る.このように実務的にはPPP の適用数が増加して いく一方で, なぜある公共調達のケースでは, PPP を導入することにより社会的厚生が改善するのかと いう問いに対して十分な説明をするための理論的な 分析道具をまだ完全には備えていないのが現状であ る.そのため, わが国におけるインフラを対象とし たPFIが議論される巾に扔いても，PFIを適用した 際の効果について，より良い予測をするは，現段階

*キーワーズ : 官民パートナーシップ, ガバナンス, 制度設計

**正会員 京都大学大学院工学研究科都市社会工学専攻 ( (615-8540 京都市西京区京都大学桂 TEL·FAX 075383-3224)

***正会員 大連理工大学管理学院技術経済研究所

( 广 116024 中国遼寧省大連市甘井子区凌工路 2 号)
では困難であると言わざるを得ない.

一口に公共調達といっても, 事業案件によって技 術的条件や複雑さは異なる. また, 事業が実施され る地域によっても, 既存の制度的条件は千差万別で ある. 望ましい官民パートナーシップのルールは, 対 象と寸る事業案件の技術的条件や当該地域の制度的 条件に大きく依存する. そのため, 最良の結果を導く 唯一のPPPモデルといったものは存在せず, 当該案 件の技術的条件および地域的条件に適したオーダー メイドのルールを構築しなければならない. 現状で は, このような問いに優れた解答を導くほどの研究 蓄積はないものの, 本研究で, その手がかりとなる 研究蓄積のフロンティアと今後の研究の方向性を示 すことを目的とする.

以下, 2. では, 公共調達契約に関する問題点の整 理を行う. 3.では, もっとも基本的なエージェンシー 理論による考察を行う. 4. では, 実際のPFI事業に おいて外生的なリスクを分担するルールを明らかに する. 5.では, 不完備契約による分析を行い, 完備 契約理論の限界について示す. 6. では, PPPの重要 な側面である民間資金を活用することによる効果に ついて考察する.

\section{2. 公共調達スキームに関する問題整理}

\section{(1) ガバナンスとしての公共調達スキーム}

PPPに関する具体的な議論に入る前に, PPPに関 連する問題に取り組む上での分析の視点を明確にし ておこう. 伝統的な手法から PPP といったさまざま な公共調達スキームを選択する問題をガバナンスと いう視点で捉えてみよう。

ある社会資本整備プロジェクトのライフサイクル を考えた場合，そこには多くのステークホルダー(関 連主体）が含まれることは言うまでもないであろう。 インフラ施設の潜在的な需要の予測は, 学識のある 専門家によって行われるであろう. 詳細な設計は, コ ンサルタントが主に行う.インフラ施設の建設は, 建 設会社が請け負う。建設会社は発注者と直接的な契 約関係にある元請もあれば，元請と契約関係にある 
下請もある. 完成した施設は, 一般の利用に供され, 施設の維持管理から, 運営上のソフト上の工夫等, よ り多くの主体が関連することになる. 以上に挙げた 全てのステークホルダーは, それぞれの定められた 権限や義務の範囲において, インフラ施設の価值に 関わるさまざまな意思決定を行っている. すなわち, インフラ施設の効率性は, ライフサイクルの中で登 場するステークホルダーの一連の意思決定によって 構成されていると言えるであろう.

以上のように，インフラ施設整備の効率性は，多 岐にわたるステークホルダの意思決定に大きく依存 している.ところが，それぞれのステークホルダー が，どのように物事を決めているかを考えてみると， 意識している意識していないに関わらず，何らかの 原理・原則に則って意思決定を行っているものであ る.このような原理・原則は意思決定原理 (decision principle）と呼ばれる6). 多くのステークホルダーが 存在する中で, 主体がそれぞれの意思決定原理に基 づいて意思決定すれば，ステークホルダー間で利害 が対立するような状況も当然存在する. ステークホ ルダーの意思決定は，互いに影響を及ぼし合うゲー 么的環境の中で形成されていく．このようにして形 成される一連の意思決定が, 必ずしも社会的に望ま しいものになる保証はない。これらの意思決定は何 らかの形で, コントロールされるべきであるのか, さ れるべきではないのか, されるべきであるならば, ど のような方法で意思決定をコントロールすることが 望ましいのかを議論していかなければならない。

以上の問題は, 関連する社会制度としてのルール や慣行と密接に関連している. 社会制度が存在する からこそ, われわれの社会における活動が一定の秩 序を保っている．意味のある制度は，われわれがあ る特定の行動をとる誘因（インセンティブ）に働き かける力を持っている7). 社会資本整備に関わる多く のステークホルダーの行動や意思決定が, その効率 性を決定することを考えれば, 公共調達スキームと いう制度を適切に設計することによって,これらの 行動や意思決定を社会的に望ましい方向一導く, す なわちガバナンス（統治）することができる.

適切な制度の設計とは, 具体的に何を意味するの か. Williamson は適切な制度を設計することによっ て, 契約に関連するすべての非効率要因 (hazard) を 費用対効果的観点から改善することができることを 主張している ${ }^{8)}$. 彼は, これを広義の意味で取引費用 の削減と定義している. 言い換えれば, 物やサービ スの取引を行うためには, 付加的にさまざまな費用 が伴う.また, 取引主体が機会主義的であれば, ホー ルドアップ問題等のように, 取引主体の行動自体が
非効率を生み出す原因にもなる。適切な制度は，以 上のような意味において，包括的な非効率を削減す るものでなければならない.

以上のように, 公共調達スキームの問題をステー クホルダーをガバナンスするための制度設計問題と して捉えなすことにより, 多様な公共調達スキーム の相違が経済的な意味で事業の効率性に与える影響 について分析が可能になる.

\section{(2) 契約の役割}

上述のように, 公共調達スキームの選択問題をガ バナンスとして捉えることにより, 調達スキームの 経済的価值を明確にすることができる，公共調達を ガバナンスする制度的な仕組みでも, 最も重要なも のが契約である. 通常, 経済的主体が取引を行う際 には，まず契約が交わされる．伝統的な公共調達の 場合でも，発注者である公共主体と請負者である民 間企業の間で請負契約が締結される．そこで，契約 形態が事業の効率性に与える影響を分析するための 視座を与えるために，まず契約の役割について明ら かにしておこう．経済学的視点からは, 契約は 2 者 間で双方の行動について双務的コミットメントする ことに関する合意であると理解される ${ }^{9)}$. 寸なわち, 契約は双方の合意によって形成されるルールである. このコミットメントは, 裁判所による法的強制力に よって実効性あるものとなる. 合理的な意思決定者 が自己の将来の行動を制限することを約束しようと するのは, 制限の期待利益が期待費用を凌駕すると きのみである10).

新古典派経済学では, 即時的取引において行われ る選択行為に焦点が当てられる.すなわち, 取引主 体は, 取引に合意するやいなや, 取引は終了してお り，その間には不確実性が介在する余地はない。しか し, Cooter and Ulen ${ }^{10)}$ は, 現実のほとんどの取引に おいて, 約束を交換する場合には, 即時的取引では なく、「時間のかかる交換 (deferred exchange)」, あ るいは「完結までに時間が経過するような交換」を 問題としているとし，このような状況にこそ契約が 存在する価值があるとしている.

契約の役割を見るために，ひとまず，時間がかか る交換を行う場合に, 契約が仮に存在しないような 状況を想定してみよう. 取引を行うために少なくと も一方の取引主体は, 取引が行われることを前提と して, 履行のための準備をする. その準備には, 当 然費用が伴う. また, 約束後に取引主体の取引環境 が変化し, 取引から価值が生み出されない状況にな る可能性もある。このような状況で契約が存在しな ければ，取引相手による事後的に取引しない等の機 
会主義的行動を事前に予想する取引主体は，取引を 行うために時間をかけて準備を行わない可能性があ る. したがって, 契約の存在意義は, このような取 引主体の機会主義的行動によって生み出される取引 のリスクを制限することを目的としている.

取引に時間がかかることによって発生する問題は, 契約締結からその履行までにさまざまな偶発的事態 が起こることである. その結果, Cooter and Ulen ${ }^{10)}$ によれば，契約の成立と履行との間に時間がかかる ために発生する問題の中で最も経済学的に重要なも のは 1 ）偶発的事態に対する責任を取引当事者間で 分配することと，2）情報の交換を促進することで ある。

契約が取引に時間がかかるからこそ意義があるの であれば，社会資本整備に関わるプロジェクトにお いて，なぜ契約が重要であるかについての本質が分 かるであろう．社会資本整備プロジェクトの重要な 特徵の一つは，その長期性にある。契約の存在なく して，プロジェクトは成立し得ないであろう。とこ ろが，次に示すように，さまざまな要因により，上 述の契約の機能は不完全なものとなる.

\section{(3) 契約の役割の不完全性}

契約が上述した意味において完全にその役割を果 たし機能するのであれば，新古典派経済学において， 標準的に想定されるような「完全競争市場均衡モデ ル」の世界が成立するであろう，そこでは，現在の 技術水準のもとで最も効率的な資源配分を実現する ように経済活動をコーディネートする一つの仕組み である ${ }^{11)}$. Arrow=Debreuの一般均衡モデルあるい はコースの社会的費用モデルが前提とする世界では, 私的所有権の初期分布が外生的に与えられれば，そ こから相互に利益となる権利の取引が自然発生的に 進化することになる12)

ところが実際には, 取引交渉に始まり, 取引が終 了するまでに, 契約の役割を機能させるために, 多 くの副次的な費用を要したり, 情報が共有化できな いといった現実的な制約が存在している. そのため, 結果的に Arrow=Debreu の一般均衡モデルで表現さ れる世界との比較の意味において, 効率的な取引を 妨げることになる。このような制約を所与とした場 合に，非効率をいかにして小さくするかということ が Williamsonが主張する制度設計の役割である. 本 研究では, PPPを公共調達のための制度と考え, 以 上で述べたような経済学的視点から望ましい公共調 達スキームについて考察する.

\section{(4) PPP の本質的問題と分析手法}

まず，PPP と伝統的な調達手法の違いについて明 確にするため, 社会資本整備プロジェクト分野にお ける公共調達契約の構造を特徵づける要因を明らか にしよう。

\section{a) 建設・運営維持管理一貫契約}

PPPでは，これまでの伝統的な公共調達方式のよ うに，民間事業者がインフラ施設を建設するだけで はなく, 建設から運営維持管理まで一貫して行う契 約を締結することが特徴的である.このように，異 なる段階間を一括して長期契約を結ぶことはバンド リング (bundling) と呼ばれている.これにより，民 間事業者は伝統的スキームの建設・運営分離方式と は異なり，建設段階においてライフサイクル全体を 通じて効率的となるような施設の建設を行うインセ ンティブを引き出すことができる，ただし，石等 ${ }^{13)}$ が指摘しているように，民間事業者が有限責任制度 によって保護されていることを考慮した場合，必ず しも民間事業者がライフサイクル全体で効率化を図 らない可能性がある.

\section{b) 民間への権限委譲}

PPPでは，全体的に社会資本の建設および運営に 関する多岐にわたる意思決定の裁量が，契約書とし てフォーマルな形で民間企業に委諒されていること が特徴である。 また，契約の期間が従来の公共調達 契約と比較して長期にわたる継続的関係を前提とし ている．すなわち，社会資本に関わる公共サービス の提供は施設の建設と運営管理によって構成される が，建設から運営管理まで一貫して民間企業に委託 されることになる．さらに，社会資本整備に必要な 初期投資に要する費用は，民間企業が資金調達を行 うことになる.このとき，必然的に投資家や銀行が 同時に事業のステークホルダーとなる．この効果に ついては，6.において詳しく説明する.

また，すべての公共サービスを民間セクター主導 で実施することが必ずしも効率的であるとは限らな い. そもそも, 公共調達の仕組みについては, 極めて 多様なリスク分担およびガバナンス構造が存在する ために, PPPの特徴について正確な定義をすること は難しいが，一般的には,「政府と民間のパートナー の間で結ばれる長期にわたる建設とサービスに関す る契約」とされている5).

以上のような, 伝統的な公共調達契約との比較し た場合のPPP の契約形態の特徵が，さまざまな所与 とすべき技術的条件や制度的条件の下で，事業の効 率性に与える影響について分析することが，経済学 的視点から見たPPP分析の主眼となる.

次章以降では，これらの問題を分析するための道 具として，契約の経済理論について説明する．3.で 
は，まず完備契約理論の理論的特徵を示し，PPPに 関連した問題における分析範囲について明確にする. 次に, PPP プロジェクトを実施する上で, もっとも重 要な要素の一つであるリスク分担原則について，4. で説明する. 5.では，完備契約理論では分析ができ ない適切な権限委譲のあり方を分析するために, 不 完備契約理論の考え方が有用であることを指摘する.

\section{3. 完備契約理論}

\section{（1）情報の非対称性}

本章では，PPPの制度設計のために，契約理論 14）-19)に基づく方法論からスタートすることの有効 性について述べよう。契約理論は，経済主体が望ま しい行動をとるインセンティブ（誘因）をどのよう に与えるかを考察する理論である．官民パートナー シップに対して契約理論を用いて分析する枠組みで は，公共主体と民間企業の関係はサービス提供の依 頼人 (principal) と代理人 (agent) というエージェン シ一関係と位置づけられる.このようなエージェン シー理論 ${ }^{20)}$ では，善意的な公共主体は公共サービス 提供の依頼人として，民間企業の行動が実現可能な 範囲で社会的厚生を最大化するように導くための誘 因体系を設計する，仮に依頼人が代理人の行動をす べて観察できる (observable) のであれば, 代理人の 行動を直接的に強制することが可能となり，契約設 計問題は自明である。ところが，現実的には代理人 の行動を完全に観察することは不可能なケースが多 い. 一般的にエージェンシー理論では，2つのタイプ の情報の非対称性を前提とする。 一つは契約締結後 の代理人の行動が観察できない場合（モラル・ハザー ド)であり，もう一つは契約締結以前の代理人が私的 情報を保有している場合（逆選抜）である．民間企業 の経済活動の誘因は，一般的には活動から得られる 金銭的利潤の獲得にある。したがって，情報の非対 称性が存在している状況においては，民間企業は自 らの利潤を最大化することを目的関数として意思決 定を行うため，必ずしも社会的な観点から望ましい 結果を導かない可能性がある. したがって, エージェ ンシー理論では, 最終成果に連動した適切な報酬ス キームを設計する問題を分析することになる．エー ジェンシー理論の一般的な帰結は, 代理人のインセ ンティブを引き出すためには，代理人に一定の情報 レントを帰属させなければならないということであ る．情報の非対称性が深刻であり，情報レントが無 視できない場合には，取引の成立可能性の低下につ ながる.

\section{(2) 情報の非対称性と PPP}

Bentz et al. $(2002)^{21)}$, Iossa and Legros $(2004)^{22)}$ は, PPPの特徵として, 建設段階と運営段階におけ る代理人が同一であることに着目している. 請負者 が建設段階で採用する努力水準は, 将来の運営段階 における維持管理費用の多寡に影響を与える。しか し, 建設段階で建設請負者が選択した努力水準は外 部から観察できないため, モラル・ハザードの問題 が引き起こされる．また，運営段階における維持管 理費用の多寡について, 民間企業である運営請負者 にとっては観察可能であるか費用をかけることによ って情報を獲得することができる状況を想定しよう. すなわち, 運営請負者は真に必要な維持管理費用に 関する私的費用を保有しているという逆選抜の問題 が引き起こされる.

Bentz et al. $(2002)^{21)}$, Iossa and Legros $(2004)^{22)}$ によれば, 以上の前提条件のもとで, 伝統的な調達 手法を用いる場合には，建設段階の請負者に対して， 将来の真の維持管理費用に関する情報を知らないこ とから, 将来の維持管理費用の不確実性を考慮した 期待費用を支払い, 運営段階の請負者に対しては, 逆 選抜による情報レントが支払われる。一方，PPPを 用いる場合には, 請負者がすでに運営段階の維持管 理費用について知識を有することから，逆選抜によ る情報レントが生じるものの, 建設段階の投資は内 部化されることになる。したがって，事前の投資費 用が小さい場合には，PPPの方が有利であるという 結果が導かれる。

\section{(3) 完備契約理論の限界}

完備契約理論では, 将来起こりうるすべての事象 を無費用かつ立証可能な形で契約に記述することが でき, さらに，そのすべての事象に対して，利得配 分の結果や対応方法が記述されているという前提が 暗黙のうちに仮定されている. 仮に, このような理 想的な契約が記述できれば，事後的な再交涉の可能 性もなく, したがって, 運営方針に関する権限, 維 持管理業務の執行の権限といった権限配分の問題を 考えること自体，意味を持たなくなる. したがって， 完備契約理論によって扱える問題の範囲は, どの業 務については誰が権限を有するかといった前提がア プリオリに与えられており，かつ情報の非対称性が 存在するという前提条件のもとで, どのようなリス ク分担スキームを望ましいかという問題に限定され ることになる. 次章では, PPP事業におけるリスク 分担のあり方について明らかにする。 また, 権限配 分の問題は, $\mathbf{5 .}$. 不完備契約理論の考え方とともに 説明する. 
表－ 1 PFI事業の調査・設計・建設段階におけるリスク

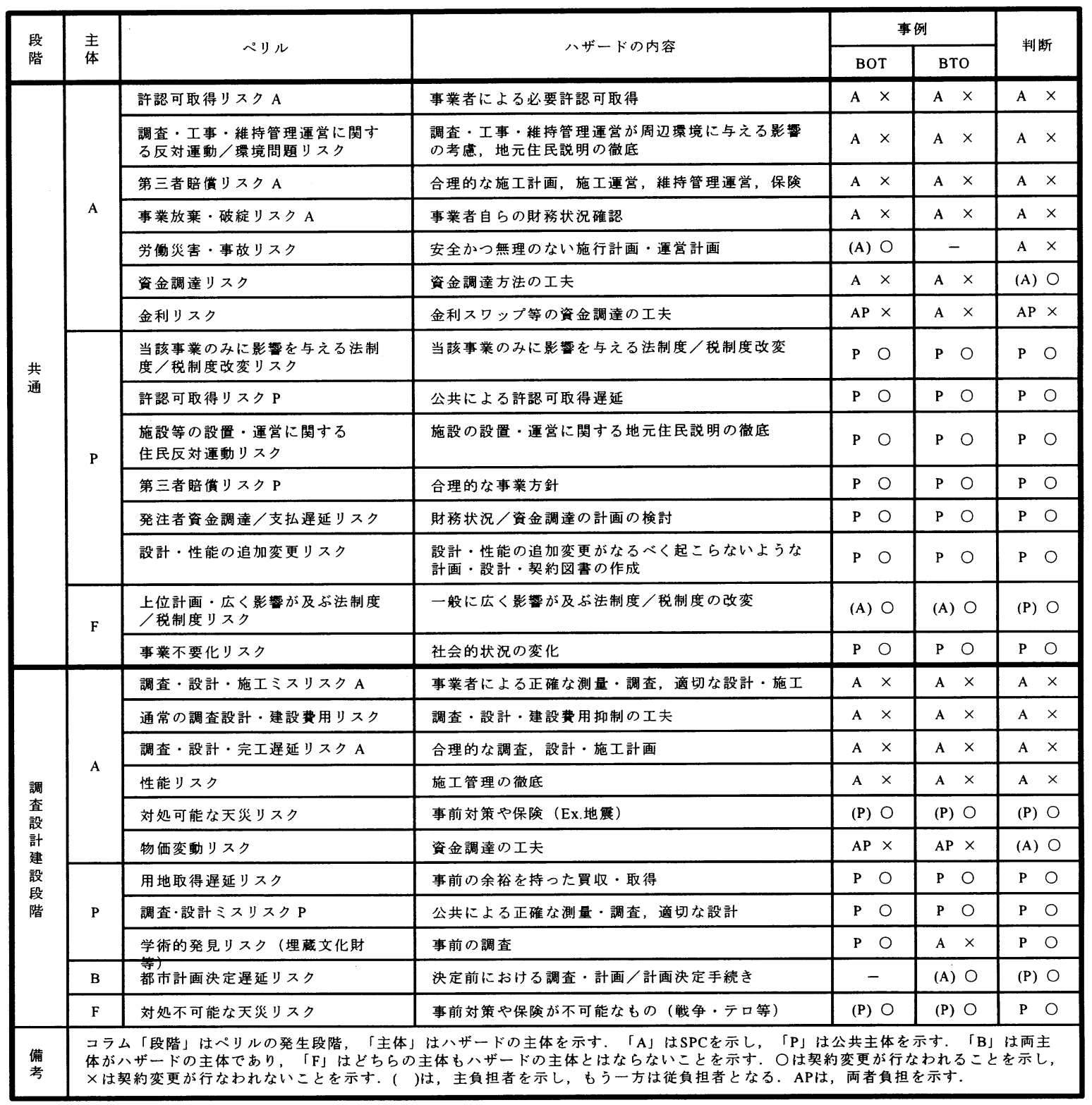

4. 外生的リスクとリスク分担原則

\section{（1）外生的リスクの種類}

外生的リスクとは，契約当事者による制御が及ば ないペリルによって発生するリスクである. PFI事業 では, 施設建設段階のみならず, 施設運営段階のリス ク事象に関しても，その効率的なマネジメントが要 請される．表一 1 にはPFI事業の調査・設計・建設 段階で発生する代表的なリスク事象に対して,「起こ りうる損失発生の直接的原因」であるペリル (peril) と「ペリルの生起とそれによる損失の規模に影響を 与える当事者の行動」である八ザードを整理してい る. 同じく, 表一 2 にはPFI事業の運営段階におけ
るリスクを整理している．ペリルと八ザードの相互 作用により，予想と実際の結果に相違が生じ，結果 として損失が生じるリスクが影響を受ける。わが国 ではPFI事業に関する標準契約約款が存在していな い，そこで，過去に実施されたPFI事業の募集要項 に基づいて，各ペリルに対するハザードの主体を想 定した。なお，事例として，BOT方式では「長岡市 高齢者センターしなの（仮称）整備，運用及び維持 管理事業」を，BTO 方式では「中央合同庁第 7 号館 整備等事業」をとりあげている.

(2) リスク事象とリスク分担原則

リスク分担の問題は「リスクにより発生した損失 
をどちらの契約当事者に帰属させるべきか」という 問題である。法経済学では, 契約法におけるリスク 分担を「もし，そのリスク事象が発生することを事 前に予見できていた場合，契約当事者がその費用を どのように分担すべきか」を問う問題として定式化 する ${ }^{23)}$.ここから，2つのリスク分担原則が導かれ る.第 1 にリスクはリスクの大きさと確率をより正 確に評価し，それを制御できる主体が負担すべきで ある。一方の主体がリスクを軽減する能力を持つ場 合，その主体にリスクによる損害を帰属させること により，効率的なリスク回避努力がなされることが 期待できる.さらに，いずれの当事者もリスクを評 価, 制御できない場合には，2）そのリスクをより 容易に引き受けることができる主体が負担すべきで ある24)。

PFI事業権契約が一度締結されれば，どちらの当 事者も他方の当事者の同意がない限り契約内容を変 更することはできない. しかし, 事業権契約は不完備 契約であり, 契約締結後に契約内容の変更が生じる 可能性がある. 法経済学における一般的な見解25),26) によれば，契約変更を認めることにより契約当事者 双方の利益が増加する場合において契約変更が正当 化される.このような契約変更原則に基づけば，本 来 SPC が負担すべきリスク事象に関して生じた損失 はSPC 自身が負担すべきであり契約変更は認められ ない，公共主体側が負担すべきリスク事象に関して は，「契約変更を認めることにより，公共主体側に注 意努力を増加させる誘因がより大きく働き，契約の 効率化を達成できることが可能となる」ため, 契約 変更が正当化される。なお，公共主体，SPCに帰属 しないハザードが原因となって生じるリスク事象に 関しては，1）契約変更により，契約の効率性を向 上できる場合や，2）リスク負担能力の大きい当事 者がリスクを負担することにより，他方の当事者の 効率的な行動を誘導できる場合には，契約変更が正 当化できる.

\section{(3) 外生的リスク分担ルール}

現実のPFI事業契約では，将来に起こりうる外生 的リスクに関する事象について，ある程度の精緻さ を持って抽出され，そのリスク分担に関するルール が取り決められる.リスク事象に関する項目内容あ るいはその精緻さは事業案件ごとに異なる．外生的 リスクの分担に関しては，1）どの主体がリスクを 負担するのか，2）主体はリスクを全て負うのかあ るいは一部か，3）一部負担の場合はその範囲を決 定するルールについて取り決められる. 表一 1, 表一 2 には, 過去のPFI事業の実施要項に示されている
リスク分担表に基づいて, 各事業で想定されている リスク分担者を整理している. 同表には前述のリス ク分担原則に従って，筆者らが望ましいと考えるリ スク分担ルールも併記している. 概ね, 過去の事例で は本稿で考察したリスク分担原則に従った分担ルー ルが採用されている，ただし，本稿でとりあげた事 例では, 都市計画決定遅延リスクを原則として SPC が負担すべきとしているが，当該リスクのハザード 主体を考えれば公共主体が主たる負担者となるべき だろう. また, 上位計画, 法律の一般的な改変は, 不 可抗力リスクに分類される場合もあり 27$)$, 主として 公共主体が負担すべきリスクである。一方，わが国 では, 天災リスクは不可抗力であり, 公共主体が負担 すべきであるという議論がある. しかし, 現在災害 保険が利用可能となりつつあり, 公共主体より $\mathrm{SPC}$ の方がリスクヘッジのインセンティブが高いことを 考えれば,一概にこの議論は正当化されない.

\section{(4) 事業方式とリスク分担ルール}

$\mathrm{BOT}$ と BTO の本質的な差異は, 施設に対する所 有権にある. したがって, BOT と BTOの場合では維 持管理運営段階の部分で大きな違いが生じる. 表一 2 に示すように，施設に対する所有権の所在により リスク負担者が大きく異なる場合がある. BOT の場 合, 施設の維持管理責任はSPCにあるが, BTOの場 合には公共主体にある. 維持管理段階のリスクの中 で，BOTとBTOにより負担者が異なるリスクとし ては, 計画/性能変更リスクと維持管理費リスク, 瑕 疪担保責任リスクがある ${ }^{28)}$. 瑕疪担保責任リスクは SPCがリスク負担者であるが, 運営方式により負担 内容が異なる. BOTでは, PFI事業者が施設を保有 するため，年限を問わず瑕疵リスクを負うこととな る. しかし, BTOの場合, 事業権契約において建設 に関する契約が委任であるか請負であるかでSPCが 負うべきリスクの大きさが決定的に異なる. 残念な がら, 事業権契約が委任契約・請負契約のいずれに 該当するかに関して現在のところ明確な規定はない. 仮に，事業権契約において建設契約が委任契約と明 確に規定されている場合, SPCは瑕疪担保期間中に おいて生じた瑕疪責任に関して，それが善良なる管 理者の注意 (善管注意) を以て設計・施工されていれ ば責任を問われない（民法644条）。しかし, 請負契 約と規定されていれば, SPC は瑕疪担保期間中に善 管注意を持って設計・施工したかに関わらずその責 任を負う。.また, 施設管理瑕疵によって発生した第 3 者への損害に対する責任に関する議論に関して明 確な見解は現在のところはっきりしていない. SPC によって設置管理される施設が「公の造営物」に該 当するならば，国家賠償法第 2 条第 1 項に基づいて 
表－2 PFI 事業の運営段階におけるリスク

\begin{tabular}{|c|c|c|c|c|c|c|c|}
\hline \multirow{2}{*}{$\begin{array}{l}\text { 段 } \\
\text { 階 }\end{array}$} & \multirow{2}{*}{$\begin{array}{l}\text { 主 } \\
\text { 体 }\end{array}$} & \multirow{2}{*}{ ペリル } & \multirow{2}{*}{ 八ザードの内容 } & \multicolumn{2}{|c|}{ 事例 } & \multirow{2}{*}{\multicolumn{2}{|c|}{ 判断 }} \\
\hline & & & & BOT & B T O & & \\
\hline \multirow{15}{*}{$\begin{array}{l}\text { 共 } \\
\text { 通 }\end{array}$} & \multirow{7}{*}{ A } & 許認可取得リスク A & 事業者による必要許認可取得 & A & $\mathbf{A} \times$ & A & $x$ \\
\hline & & $\begin{array}{l}\text { 調查·工事・維持管理運営に関する } \\
\text { 反対運動/腺境問題リスク }\end{array}$ & 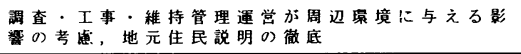 & A & A & A & $x$ \\
\hline & & 第三者賠偵リスク A & 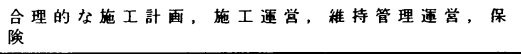 & $x$ & A & A & $x$ \\
\hline & & 事業放菓・破缩リスク A & 事業者自らの財務状況確認 & $\times$ & A & A & $x$ \\
\hline & & 下請到産リスク & 選定する下請ひ状況把握 & - & A $\times$ & A & $x$ \\
\hline & & 资金調诖リスク & 资金調達方法 $\sigma$ 工 & $\times$ & A & (A) & $\mathrm{O}$ \\
\hline & & 金利リスク & 金利スワップ等の瓷金調達の工夫 & A P $\times$ & A $\times$ & A P & \\
\hline & \multirow{6}{*}{$\mathbf{P}$} & $\begin{array}{l}\text { 当該事業のみに影䇾を与える法制度 } \\
\text { 税制度改変リスク }\end{array}$ & 当該事業のみに影響を与える法制度/税制度改変 & $\mathbf{P} \quad \mathrm{O}$ & $\mathbf{P} \quad \mathrm{O}$ & $\mathbf{P}$ & $\mathrm{O}$ \\
\hline & & 許認可取得リスク P & 公共による許認可取得遅延 & $\mathrm{P} \quad \mathrm{O}$ & $\mathbf{P} \quad \mathrm{O}$ & $\mathbf{P}$ & $\mathrm{O}$ \\
\hline & & $\begin{array}{l}\text { 施設等の設管・運営に関する } \\
\text { 住民対運動りスク }\end{array}$ & 施設の設置・運営:関する地元住民説明の徽底 & $P \quad O$ & P O & $\mathbf{P}$ & C \\
\hline & & 第三者賠借リスク $\mathrm{P}$ & 合理的な事菜方針 & O & 0 & $\mathbf{P}$ & O \\
\hline & & 発注者資金調達／支払䐅延リスク & 財務状況／瓷金調详計画 0 検討 & $\mathbf{P} \quad \mathrm{O}$ & $\mathrm{P} \quad \mathrm{O}$ & $\mathbf{P}$ & O \\
\hline & & 設計・性能り追加変更リスク & $\begin{array}{l}\text { 設計・性能の追妿変更がなるごく起こらないよう } \\
\text { な計画・設計・䒜約图書の作成 }\end{array}$ & P O & $P \quad O$ & $\mathbf{P}$ & 0 \\
\hline & \multirow{2}{*}{-} & $\begin{array}{l}\text { 上位計画・広く影䇾が及ぶ法制度 } \\
\text { 税制度リスク }\end{array}$ & 一般に広く影揞が及ぶ法制度／税制度の改変 & (A) 0 & (A) $\mathrm{O}$ & (P) & $\mathrm{O}$ \\
\hline & & 事蕃不要化リスク & 社会的状況の変化 & $\mathbf{P} \quad \mathrm{O}$ & O & $\mathbf{P}$ & 0 \\
\hline \multirow{18}{*}{$\begin{array}{l}\text { 維 } \\
\text { 持 } \\
\text { 管 } \\
\text { 理 } \\
\text { 運 } \\
\text { 営 } \\
\text { 段 } \\
\text { 階 }\end{array}$} & \multirow{11}{*}{ A } & 運営關始遅延リスク A & 事菜者による迅速な運営開始手繶き，保哈 & A & $\mathrm{A} \times$ & A & $x$ \\
\hline & & 劣化早期進行リスク & 劣化の不確実性を考港した維持管理計画 & $x$ & $x$ & A & $x$ \\
\hline & & $\begin{array}{l}\text { 設計・施工瑕庭リスク（最長 } 10 \text { 年ま } \\
\text { で) }\end{array}$ & $\begin{array}{l}\text { 設計・施工段階に扰ける仕様に従う妥当な技術と } \\
\text { ケア }\end{array}$ & $x$ & - & A & $x$ \\
\hline & & 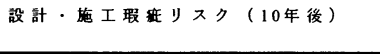 & $\begin{array}{l}\text { 設計・施工段階における仕样に徉う妥当な技術と } \\
\text { ケア }\end{array}$ & $x$ & - & $\mathbf{P}$ & $x$ \\
\hline & & 施設管理理峦リスク A & 施設管理 の徹底 & $x$ & A & A & $x$ \\
\hline & & 維持管理費リスク A & 事羓者による維持管理方法の工夫 & A & - & (A) & $\mathrm{O}$ \\
\hline & & 需要リスク & 施設連営 $\sigma 工 夫$ & $x$ & $A \times$ & (A) & 0 \\
\hline & & サーヒスス水準 /吽能未澾リスク & 運営管理 $\theta$ 敞底 & A & A $\times$ & A & $x$ \\
\hline & & 対処可能な天災りスク & 事前対策や保倹（Ex.地震） & (P) 0 & (A) 0 & (A) & O \\
\hline & & 事故・火災リスク & 事故減少・火災対策，保㢵 & A 0 & - & (A) & 0 \\
\hline & & 物価リスク & 资金渭澾の工夫 & PA ? & A P ? & (A) & 0 \\
\hline & \multirow{5}{*}{$\mathbf{P}$} & 運営開始逮延リスク P & 公共による迅速な運営開始手続き & $\mathbf{P} \mathrm{O}$ & $\mathbf{P} \mathrm{O}$ & $\mathbf{P}$ & 0 \\
\hline & & 計画／性能変更リスク P & $\begin{array}{l}\text { 公共によるより道切かつ効率的な計画/性能変更 } \\
\text { の年 }\end{array}$ & $\mathbf{P} \quad 0$ & O & $\mathbf{P}$ & O \\
\hline & & 維持管理費リスク P & 公共による維持管理方法り工夫 & $\mathrm{O}$ & - & $\mathbf{P}$ & O \\
\hline & & 周辺インフラリスク & 公共による事前 $の$ 綿密な計画想定 & $\mathbf{P} \quad \mathrm{O}$ & $\mathbf{P} \quad \mathrm{O}$ & $P$ & 0 \\
\hline & & 事莱期間延長リスク & 事業期間の延長が必要とならない事業計画 & $\mathbf{P} \quad 0$ & O & $\mathbf{P}$ & O \\
\hline & \multirow{2}{*}{$\mathbf{F}$} & 対処不可能な天災リスク & 事前対策や保険が不可能なもの（栈争・テ口等) & (P) $\mathrm{O}$ & $\mathbf{P} \mathbf{O}$ & $\mathbf{P}$ & 0 \\
\hline & & 技術革新に上る事䎹の陳腐化リスク & 技術革新 & - & - & $\mathbf{P}$ & 0 \\
\hline
\end{tabular}

公共がその責任を負い, SPCが公共から求償される のみであるという見解が有力であるとされる29).

施設所有者が公共主体かSPCかの違いは, 施設 管理上の瑕疪責任の所在に影響を及ぼす. BOTの場 合、SPCが管理层疪責任を負う。一方、BTOで施 設運営がされている場合, 第 3 者に発生した損害に 対する管理瑕疵責任の所在に関して現在のところ明 確な見解の一致を見ていない。公共主体が施設所有 権を保有している場合, 公共主体が一時的にその不 法行為責任を負うが, 施設管理はSPCが実施してい る。不法行為責任を SPCに転嫁できるか否かは，管 理契約が委任であるか請負であるかに依存しよう。 委任契約であれば, SPCが善管注意義務を果たして
いる限りにおいてその責任を免れる。しかし，請負 契約では，その責任は絶対である.PFI事業におい て管理层疵リスクは無視できないものであり、管理 責任に関する法的な規定が急がれる.

\section{5. 不完備契約アプローチ}

\section{(1) 不完備契約と官民パートナーシップ}

公共サービスの調達スキームに関する議論の本質 的な意味を明らかにするために，公共主体と民間事 業者の間で完備契約 (complete contract) が記述で きる状況を仮定しよう，完備契約とは，契約書に将 来に起こりうるすべての事象を記述できるだけでは 
なく, 起こった事象ごとの義務（エージェントのとる べき行動，収益の配分）も裁判所で立証可能できる （verifiable）形で記述した契約として定義される ${ }^{20)}$. 仮に，公共主体と民間事業者の間で完備契約が可能 であれば, 所有権構造は無意味であり，すなわち，民 営化やPFI といった議論にも意味がない30)-48)。な ぜならば，公共主体と民間事業者の間でいったん完 備契約が締結されれば，契約締結後にいかなる事象 が生じたとしても，契約の記述事項にしたがって意 思決定が行われ，収益の配分が確定する．このとき， 所有権がいずれの帰属しているかどうかは，契約の 結果には影響を与えないことになる。あるいは，公 的企業が何らかの理由で民間事業者よりも劣ってい たとしても，完備契約が記述可能な世界では，公共 主体は民間事業者の組織や契約をそのまま採用する ことによって，経営者や労働者に民間事業者と場合 と同じ行動をとらせることができる ${ }^{41)}$. 換言すれば, 公共サービスの調達スキームに関する議論は，不完 備契約 (incomplete contract) ${ }^{49), 50)}$ の世界を前提と しない限り，無意味であることがわかる。

契約の不完備性に起因する問題は, 取引当事者間 で情報の非対称性が存在しない場合でも起こりうる 問題である。このような要因が, 社会資本整備プロ ジェクトにおいて，見られる顕著な特徵であること は，契約実務に携わる方々にとれば，ほぼ自明であ ろう。本研究の動機は，契約の機能を不完全にする 要因としての契約の不完備性に起因寸る問題を詳細 に検討し, 社会資本整備プロジェクトの効率化を図 ろうとすることである. 契約の不完備性については, 次節において詳細に説明しよう。

\section{(2) 不完備契約における所有権の役割}

PFI事業では，当該選定事業だけを対象として建 設から運営までを担う特別目的会社 (Special Purpose Company, 以下 $\mathrm{SPC}$ と略す）が設立される. $\mathrm{SPC}$ は当該事業から得られるキャツシュフローのみ をもとに事業費の回収を図る.PFI事業権契約には， $\mathrm{SPC}$ が義務として守るべき性能，サービスの内容が 記載される。しかし，PFI事業権契約において，政府 が対象とする施設・サービスの要求性能について詳 細に記述することは不可能である。また，契約期間 が長期にわたるため, 運営期間中に要求性能の変更 や新しい技術が利用可能になる可能性が大きい。こ の場合, 運営段階で事業権契約の変更が必要となる. 事業権契約の入札の段階とは異なり，運営段階では 契約当事者の交渉により契約変更が議論される。こ のため, 契約当事者が契約変更において交渉力を発 揮し，自己にとって有利な方向に交涉結果を誘導し
ようとする. とりわけ, 契約当事者が事業権契約に 対して行った投資は, 当該事業のみに有効な取引特 殊的投資である場合が多い. 契約変更に関する交渉 の結果，過去の投資を実施した主体が，投資が生み 出した余利の一部しか獲得できないという事態が発 生する.このような状況が予想される場合, 契約当 事者の事前の投資水準が過小になるというホールド アップ問題が発生する可能性がある.

不完備契約理論では, ホールドアップ問題の構造 に契約対象物件の所有権の帰属が本質的な役割を果 たすことが指摘されている51)-58). そこでは, 所有 権は残余決定権（residual control right）と定義され 「契約に書かれていないことが起こったときの意思決 定に関する権限」を意味する.

契約に規定されない状況が発生するとき, 契約当 事者間で再交涉が行われるが, 残余決定権は再交渉 の利得の配分を決定する重要な要因となる。特に, PFI事業におけるサービスの質的水準を要求性能と して完全に記述することは不可能であり, SPCが費 用削減を図り, その結果としてサービス水準が低下 するリスクが存在する. 施設の所有権が政府にあれ ば, SPCが施設を改変するためには政府の同意が必 要となる. しかし, SPCが所有権を所有している場 合，SPCは事業権契約に記載されていない事項につ いて改変する裁量権を持つ. サービスが低下したと しても，それを司法当局や第 3 者に立証できない場 合が少なくない.このような状況では, 政府と SPC がサービス水準の変化をめぐって再交涉を行っても, 政府がサービス水準の低下によって生じた損失すべ てを回復できない可能性がある。このような再交渉 時の利得再配分における交涉力の多寡により, PFI 事業のサービス水準が影響を受ける.この例でも理 解できるように, PFI事業における所有権の帰属は, 事業の長期的な効率性に多大な影響を及ぼす可能性 がある. 本研究では所有権の帰属という視点から， BTO, BOT方式の効率性を分析するとともに, ホー ルドアップ問題を抑制しうるインセンティブ契約ス キームについて分析する.

ちなみにPFI事業において所有権が問題とされ る. しかし, 施設所有権が実際にどのような意思決 定に関する権利なのかが，必ずしも明らかになって いない，また，所有権に関する権利は，それぞれの 国により異なる。

\section{(3) 官民パートナーシップスキームの権限配分}

Laffont and Tirole ${ }^{36)}$ は, 公共主体の民間事業者 に対する介入のパターンによって, 官民パートナー 
表-3 企業形態の分類

\begin{tabular}{|c|c|c|}
\hline & \multicolumn{2}{|c|}{ 公共主体の介入 } \\
\hline & $\begin{array}{c}\text { 外部コント } \\
\text { ロール }\end{array}$ & $\begin{array}{c}\text { 内部コント } \\
\text { ロール }\end{array}$ \\
\hline 公的企業 & $\mathrm{O}$ & $\mathrm{O}$ \\
\hline 規制された私的企業 & 0 & $x$ \\
\hline 無規制の私的企業 & $\times$ & $x$ \\
\hline
\end{tabular}

ただし，○は，当該パターンによる政府の介入が 存在することを意味しており，×は政府の介入が存 在していないことを示している.

シップのガバナンス構造が決まることを指摘してい る.このことを説明するために，彼らは公共主体の 民間事業者に対する介入のパターンを，外部コント ロールと内部コントロールの 2 つ分類している.

外部コントロール (external control) とは, 公共 主体が民間事業者が，外部の主体との関わりに関す る変数をコントロールすることを言う. 例えば, 消 費者との関係であれば，価格や品質に関する規制等 によるコントロールがある.

内部コントロール（internal control）とは, 公共 主体が民間事業者の資源投入や費用最小化のプロセ スに関する変数をコントロールすることを言う．例 えば, 経営者に対するインセンティブスキームを通 じて, 経営者の努力という資源に影響を与えたり, 雇 用や立地，投資のタイプや借入等の意思決定への介 入等が内部コントロールに分類される.

Laffont and Tirole ${ }^{36}$ ) は，このような公共主体の介 入のパターンに応じて, 公的企業 (public enterprise )，規制された私的企業（private regulated firm）と 無規制の企業を（unregulated firm）を表一 3 に示す ように定義している.すなわち, 公的企業とは外部 コントロール, 内部コントロールの両方に関して, 政 府が介入するようなケースと定義される. また，規 制された私的企業は，外部コントロールのみに関し て政府が介入するケースと定義され, 無規制の私的 企業は，外部コントロール，内部コントロールとも に政府の介入がないケースと定義される.

ところが，現実の公共主体の介入の程度は，有限 個のパターンに分類されるわけではなく, むしろ連 続的に広がっていると解釈すべきであり, 実際の官 民の取引関係はより複雑である。このような介入の 問題は，所有権の法的性質に依拠している.

また，通常 $100 \%$ 民間資本により設立された企業 でさえ，法律や規制といった公的なルールによって， 行動が制限される. PFIや民営化といった議論は, 公 共主体が民間企業に対して, どのような介入を行う のが社会的に望ましいのか，という問題の延長にあ
る. 公共主体の介入のパターンの一例として, Laffont and Tirole ${ }^{36)}$ を示したが, 現実的には, 極めて多 様な介入の方法があり, 介入の程度も連続的に分布 しているのである. すなわち, プロジェクトのスキー 厶は比較的公的所有の度合いが強いものから, 私的 所有の強いものまで連続的に広がっている，われわ れは官民パートナーシップスキームの設計問題を所 有権の配分問題として捉えることができる. 望まし い介入の方法を決定する要因は, 提供するサービス やプロジェクトのさまざまな特徴によって決定する.

\section{（4）公的所有の非効率性}

Laffont and Tirole ${ }^{36)}$ は, 契約の不完備性に起因す る所有権の構造が，1）経営活動に関する情報の獲 得と 2 ) 所有者の目的の 2 つの視点において問題と なることを指摘している.

経営活動に関する情報獲得のインセンティブ 経 営活動に関する情報に関しては，通常，裁判所にお いて立証することができない．また，企業買収家は， 情報獲得に対して金銭的なインセンティブが働くが, 公務員の場合には，非効率な経営や潜在的な相乗効 果に関する情報を獲得するために投資する十分なイ ンセンティブを有していない.

所有者の目的 民間企業の目的は, 事業から得ら れる利潤を最大化することである.これに対して, 公 共セクターの目的は必ずしも明らかではなく，例え ば，独占価格の抑制やサービス品質のコントロール， 負の外部性の抑制，セクター毎の政策の推進，国家 的独立，不景気時の投資や雇用といったように，多 岐にわたっている59). したがって, 公共セクターは, 目的に対するコミットメントが容易ではなく，その ため経営者が報われない可能性があるため, 経営者 の努力を引き出すことができない，また，政府は特 定の利益団体から影響を受けることにより，必ずし も社会的厚生を最大化するとも限らないことが指摘 されている35)。ささらに, 公共主体の労働者は, 内在 的なモチベーションにより，しばしば最適な努力を 行っているために, 強いインセンティブシステムを 導入する必要がないとする指摘もある60).

これまでのわが国が置かれていた経済的環境を考 えれば，非効率を許容するだけの余裕があった. 公 共主体のプロジェクト方法であれば, 極めてリスク が少なくてすむ. しかし，政府の雇用による費用削 減や品質向上のインセンティブは弱い40)。ところが, 実証研究では必ずしも公的組織が根源的に非効率で あるという見方を肯定していないと指摘した研究も ある61),62). 


\section{（5）民間所有の非効率性}

民間所有においても情報の非対称性による潜在的 な費用が生じる，仮に，情報の非対称性がなければ, 必ず民間所有が公的所有を支配する. Laffont and Tirole ${ }^{35)}$ は, 経営者を政府と株主の両者のエージェン トとして位置づけ，共通エージェンシー問題63),64) と して定式化した，政府の規制から得る利益と株主の 利益に関する利害は対立するために，両者とも他の 主体との契約関係による効果を内部化できず，結果 的に民間企業の経営者に与えるインセンティブは過 小になることが指摘されている.

これに対して, Shapiro and Willig ${ }^{65) や ~}$ Schmidt ${ }^{66)}$ は，公共主体が規制するモデルとは異な り，企業の情報についてより詳細な情報を獲得でき る状況を想定しており，公的所有のメリットは企業 の情報レントを減少させることができることとして いる. また, Shapiro and Willig ${ }^{65)}$ は, 公共主体が必 ずしも社会的厚生を最大化せず，私的利益を最大化 しようとする主体であると位置づけ，規制の下での 民間所有のメリットを指摘している. Schmidt ${ }^{66)}$ は, 公共主体が社会的厚生を最大化しようとする慈悲深 い（benevolent）規制者であったとしても，通時的に コミットメントすることができないために，企業の 十分な投資を引き出すことができないことを指摘し ている.

\section{6. 金融契約の効果}

\section{(1) 資金調達モード}

前章までは，公共主体と民間企業の間の契約問題 のみに着目してきた。しかし，PPPが伝統的な公共 調達手法と大きく異なる点である資金調達モードに 関する効果については分析していない.しばしば, PFIのように民間資金を活用することで，公共主体 にとってはオフ・バランス効果が期待できるという メリットが指摘される。 しかし，経済的効率性の観 点から見れば，このような効果を期待した民間資金 の活用は正当化されるわけではない68).

次に,「PFIや民営化を実施する場合に，どのよう な契約条項や規制といった制度が望ましいか」とい う問いが生じる．PFIや民営化では，いわゆる 3 大プ レイヤー4）（公共主体，民間事業者，金融機関）が戦 略的に意思決定を行うゲーム的状況となる.これら のプレイヤーが自らの動機によって，個別の意思決 定を行うことを所与とすれば，彼らの意思決定が社 会的に望ましい方向へと導かれるようにコーディネ 一トされるべきである．意思決定のコーディネート は，機能する契約や規制を適切に設計することによ
り実現することができる。言い換えれば，規範的な PFIや民営化の制度設計に関して, 詳細な研究が必 要となる. この問題は, 後述するように, 複雑な構造 の定式化とならざるを得ないが，近年のコーポレー ト・ファイナンスに関する理論的研究の進展に伴い, PFIに関連する重要な示唆を得た研究が蓄積されつ つある。

\section{(2) 負債契約の効果}

モジリアニ・ミラーが指摘した企業の資本構成が 企業価値に影響を与えないとした論文を噙矢として, 企業の資本構成がコーポレートガバナンスに与える 影響について, 多くの研究が蓄積されてきた. 負債 契約によって, 資金調達を行うことにより, 民間企業 は破綻リスクが生じる，負債契約を締結すれば，企 業が破綻した際に, 企業の所有権は, 債権者に移転 する効果を持つ. 経営者は, 企業の存続から私的レ ントを得ることを考えれば，このような破綻リスク の存在が, 経営者の努カインセンティブを引き出す 可能性がある69)。 また，これまで，公共主体が民間 事業者の内部情報を入手することができないことに よって，民間事業者の努力を引き出すことができる ことが指摘されている30)-46).

三井 ${ }^{46)}$ は, $\mathrm{Schmidt}^{30), 38)}$ が指摘した民営化によ る内部情報遮断の効果と Aghion and Bolton ${ }^{72}$ ) が分 析した民間企業における負債の規律づけの問題を統 合したモデルを提案し, 民営化により内部情報が遮 断されることにより, 負債による規律づけ機能を通 じてソフトな予算問題52)を防ぐことが可能であるこ とを明らかにした。しかし，PFI事業の負債契約に おける返済リスクの配分問題を取り扱っていない.

一般に，PFI事業の契約期間は長期にわたり，事 業が破綻するというクレジットリスクも少なくない. したがって, PFI事業の効率的な契約スキームを分析 する上で，事業の継続が不可能になった場合におけ る返済リスクの配分を事前に設計することが重要に なってくる. Hart and Moore ${ }^{53)}$ は，返済リスクを考 慮した不完備契約モデルを提案し, 事業資産の部分 的売却が再交渉プロセスに与える影響を分析してい る.しかし, PFI事業では事業資産の部分的売却が不 可能であるため, SPCの資産売却に関する戦略的行 動が問題になるわけではない，さらに，返済リスクの 分担方法は，事後的な損失の配分だけでなく, SPC が負債契約の有限責任制を利用して，リスクの高い プロジェクト方法を選択するという資産代替にも影 響を及ぼす。このような観点から, Detragiache ${ }^{54)}$ は, 負債契約の有限責任制度の下で，事業破綻処理が事 前，事後の企業行動に及ぼす影響を分析し，企業の 
資産代替行動が発生するメカニズムについて分析し ている.これらの研究はいずれも負債契約における 返済リスクや資産代替について分析したものである.

これに対して, PFI事業は，公共主体と SPCの間 の事業権契約，およびSPC と金融機関の間の負債契 約で構成される複合的な契約であり，事業権契約と 負債契約は互いに密接に関連している。このような 特徵を持つPFI事業に対して，大西等55) は，将来の 外部経済便益の大きさが不確実な環境において, 外 部経済便益が判明後, 効率的な事業の継続及び清算 を実現するために，保証金制度及び補助金制度が果 たす役割について分析した。しかし，そこでは保証 金制度が資産代替問題のような SPC の事前の意思決 定に及ぼす影響については考慮していない.そこで， 石等 ${ }^{56)}$ は，負債契約モデルを内蔵したような事業権 契約モデルを定式化し，公共主体が有する事業解除 権の役割や，競争入札制度，保証金制度が PFI事業 の効率性に及ぼす影響について分析している.

\section{（3）金融契約と破綻処理手続き}

民間資金を調達する際には，金融契約が締結され る. 民間企業が何らかのリスクを負う限りにおいて， 金融契約の債務不履行が生じる可能性は無視するこ とができない. また, 債務不履行にともなう公共サー ビスが停止するリスクは，特にサービスの安定性が 求められるインフラ分野では致命的である。このよ うな問題意識に基づき, 大西ら ${ }^{70)}$ は, Bebchuk ${ }^{71}$ お よびAghion et al. ${ }^{72)}$ が提案した民間企業のための効 率的な倒産法制モデル（以下，BAHMモデル）に基 づいて, PFI事業のための効率的な倒産法制手続き を提案した.

PFI事業会社が民間資金によって設立され，収益 によって資金回収を行う仕組みは民営会社と相違な い. しかし，多くのPFI事業はインフラの整備及び 運営を目的とする. したがって, PFI事業の破綻処 理においては, 通常の倒産法制が想定する民営会社 の破綻処理とは重大な相違点が存在する. 倒産法制 では, 債権者の意思により事業の継続の有無が決定 されるが，そこにはキャッシュフローから算定される 企業価值と会社がもたらす社会的な価値が一致する という基本的な前提が存在する. 一方, PFI事業で は, PFI事業者が回收できない外部経済が発生する という市場の失敗が生じる. したがって, 効率的資 源配分を達成するためには，公共主体による補助金 の給付や規制等の市場介入が不可久となる場合が多 い. さらに, PFI事業権契約が事業者間の競争を通 じて締結されることを考えると, 事業の社会的経済 価値は, PFI事業者が受け取るキャッシュフローを上
回っていると考えるのが自然である.

PFI事業では公共主体による直接的な支払いや金 銭的支援が前提となっており, PFI事業者の企業価値 は事業権契約で規定されるサービス対価や補助金の 額に大きく左右される．仮に公共主体が事業権契約 の締結後に事業権契約におけるサービス対価や補助 金の額の変更を認めれば，その時点でPFI事業者の 企業価值は変化する. 換言すれば, PFI事業が破綻し た場合においても，公共主体の意思により PFI事業 者の事業価値を変化させることが可能である. 一方, 多数のステークホルダーと取引を行っている民営会 社の場合, 事業破綻後に個別のステークホルダーと 取引契約に関して再交渉することは実質上不可能で ある.このように, PFI事業では，取引相手である 公共主体との契約の再交渉が可能であり，この点で 民営会社を対象とした事業再生手続きと異なった再 生手続きを設計することが必要となる.

\section{(4) 事業継続性を高めるための仕組み}

BAHM モデルで十分に検討されていない問題と して, 事業再生時における短期流動性の調達の問題 がある. BAHMモデルによる手続きでも，再建計画 の検討や事業価值の検討等には少なからず一定の期 間が必要となる. 事業再生過程においては, 新しい事 業者が運営するにせよ, 公共主体が運営するにせよ, インフラサービスの提供を継続することが前提にな るため，事業価值を維持するための短期的な資金調 達が重要な課題となる ${ }^{73)}$.このような「つなぎ」のた めの運転資金に対するファイナンスは「DIP (Debtor In Possesion：占有継続債務者）ファイナンス」と呼 ばれる，実際には，黒字倒産といった，一時的な流 動性不足のために，破綻する例もある．Holmström and Tiroleは, 会社が通常, 常に一定の流動性資産を 保有するという行動を説明する理論モデルを構筑し $た^{74)}$. 最終的な収益が経営者の観察不可能な努力に 依存するというモラルハザードの構造が存在し, 初 期投資後に契約に記述できないような不測の事態に よって追加融資が必要になる場合を考えよう。この とき, 経営者の努カインセンティブを引き出すため に，一定の準レント（資源を経常的に利用し続ける ために必要とする最小収益の超過分）を経営者に帰 属させなければならない，そのため, 継続価值が正 であるような会社であっても，準レントが大きけれ ば金融機関がつなぎ融資をしない可能性がある。こ のため, 経営者に対するモニタリングが強化されれ ば，つなぎ融資が実現される可能性は高くなろう。こ のように効率的なつなぎ融資を担保するための制度 の構筑は, 事業の安定性が要求される事業にとって 
changing governance of built environment, $U r$ ban Studies, Vol. 35, pp. 2277-2301, 1998.

\section{7. おわりに}

本研究では，PPPを公共調達のための制度として とらえ, 経済学的視点から蓄積されてきた研究を取 りまとめるとともに，その限界について示した。近 年では, PPPの効果は, 契約の不完備性が本質であ るという合意が理論研究者の間で形成されつつある. ところが，実際の問題において，適切な公共調達ス キームを組成する際には，まだ理論研究が貢献でき るための道具は有していないというのが現状であろ う.わが国では，すでにPFIの実施例も増加しつつ ある.これらのデータから，これまでの理論研究の 蓄積を徹底的に検証していく必要があろう.

また今後，望ましい制度を導入するを推進するた めの仕組みに関する研究も必要であろう。経済シス テムの改革に成功するためには，自生的な進化と理 性的な設計という制度変化の 2 つ契機を整合化す る必要がある ${ }^{75)}$ 。新しい制度の導入の過程は, 自生 的進化のダイナミズムを読み解き，それを組み込ん で制度の理性的な設計と社会的な選択を推進する漸 進的革新とならざるを得ない，特に，制度的補完性 が存在する場合には，複数の制度を同時に変化させ る必要がある。しかし必ずしも, 制度変化の容易さ やスピードが同程度であるとは限らないという難点 がある.このような問題は，まだ萌芽的であるが今 後特に重要性が増していくものと考えられる.

謝辞 土木計画学小委員会には, 招待講演という名 誉な機会を与えていただき，ここに感謝申し上げま す. 本研究は, 第一著者が京都大学大学院博士後期 課程在籍中より取り組んできた研究テーマでありま す. 京都大学の小林潔司教授は, 常日頃から私ども の研究に対して, 博士課程在籍中には指導教授とし ての立場から非常に貴重なアドバイスをいただきま した。また, 武蔵工業大学の宮本和明教授をはじめ とする土木学会PFI研究小委員会の皆様には, 研究 会を通じて有益な議論をさせていただきました，東 京大学の上田孝行教授, 京都大学の大本俊彦教授に も日頃から常に適切なコメント及び励ましの言葉を いただきました。この場をお借りして，篤く御礼申 し上げます.

\section{参考文献}

1) Grout, P.: The economics of private finance initiative, Oxford Review of Economic Policy, Vol. 13, pp. 53-66, 1997.

2) Kerr, D.: The private finance initiative and the
3) 山内弘隆: 日本版 PFI, 地域科学研究会, 1999.

4) 西野文雄, 有岡正樹, 有村彰男, 大島邦彦, 野田 由美子, 宮本和明: 日本版 PFI, 山海堂, 2001 .

5) Maskin, E. and Tirole, J.: Public-private partnerships and government spending limits, mimeo, 2006.

6) 桑嶋健一, 高橋信夫 : 組織と意思決定（松原望 編集 : シリーズ意思決定の科学 3), 朝倉書店, 2001.

7) 清水克俊, 堀口昭義 : インセンティブの経済学, 有斐閣, 2003.

8) Williamson, O.E.:Mechanisms of Governance, Oxford University Press, 1996.

9) Brousseau, E. and Glachant, J.M.: The economics of contracts and the renewal of economics, in Brousseau, E. and Glachant, J.M. (eds): Economics of Contracts: theories and applications, Cambridge Univerisity Press, 2002.

10) Cooter, R. and Ulen, T.: Law and Economics, Harper Collins, 1988, 太田勝造訳 : 法と経済学, 商事法務研究会, 1990.

11) 礒谷明徳: 制度経済学のフロンティアー理論・応 用・政策一, ミネルヴァ書房, 2004.

12) Aoki, M.: Towards a Comparative Institutional Analaysis, The MIT Press, 2001, 瀧澤弘和・谷 口和弘訳 : 比較制度分析に向けて, NTT出版, 2001.

13）石否, 大西正光, 小林潔司: ペイオフ外部性と 性能規定型維持管理契約, 土木学会論文集 D, Vol.63, No.3, pp.344-359, 2007.

14) Laffont, J.J: The Economics of Uncertainty and Information, MIT Press, 1989, 佐藤公敏 訳: 不確実性と情報の経済学, 東洋経済新報社, 1992.

15) Akerlof, G.A.: The market for lemons: quality, uncertainty and the market mechanism, Quartely Journal of Economics, Vol.84, pp.488-500, 1970.

16）細江守紀 : 不確実性と情報の経済分析 : 九州大 学出版会, 1987.

17) Salanie, B.: The Econimics of Contracts, MIT Press, 1997, 細江守紀, 三浦功, 堀宣昭訳 : 契約 の経済学, 勁草書房, 2000.

18) Laffont, J.J and D. Martimort: Theory of Incentives: The Principal-Agent Model, Prince- 
ton, 2002.

19）伊藤秀史 : 契約の経済理論, 有斐閣, 2003 .

20) Hart, O. and B. Holmström: The theory of contracts, in T. Bewley, ed., Advances in Economic Theory, Fifth World Congress, Cambridge University Press, 1987.

21) Bentz,A., Grout,P., Halonen, M.: What should the state buy? CMPO working paper.

22) Iossa,E. and Legros,P.: Auditing and Property Rights, Rand Journal of Economics, Vol.35, pp, 356-372, 2004.

23) Posner, R. and Rosenfeild, A.: Impossibility and related doctrines in contract law: An economic analysis, Journal of Legal Studies, Vol.6, pp.83-118, 1977.

24) 大本俊彦, 小林潔司, 若公崇敏 : 建設請負契約 におけるリスク分担，土木学会論文集， No.693/VI-53,pp.205-217, 2001.

25) Aivazian, V., Trebilcock, M., and Penny, M.: The law of contract modifications, The uncertain quest for a bench-mark of enforceability, Osgoode Hall Legal Journal, Vol.22, pp.173212, 1984.

26) Miceli, T.: Contract modification when litigating for damage is costly, International Review of Law and Economics, Vol.15, pp.87-99, 1995.

27) Michel, Kerf, R. David Grey, Timothy, Irwin, Celine Levesque and Robert R. Taylor: Concessions for infrastructure: A guide to there design and award, World bank technical paper No.399 Finance, Private sector, and Infrastructure Network, 1998.

28) 大西正光, 坂東弘, 小林潔司: PFI事業にお けるリスク分担ルール, 都市計画学会論文集, No.38, pp.289-294, 2003.

29) 内閣府PFI推進委員会 : 公の施設と公物管理に 関する研究 (中間報告)，pp.18-19, 2003.

30) Schmidt, K. M.: The costs and benefits of privatization: An incomplete contracts approach, Journal of Law, Economics and Organization, Vol. 12, pp. 1-24, 1996.

31）伊藤秀史，小佐野広編著:インセンティブ設計の 経済学一契約理論の応用分析, 勁草書房, 2003.

32) Borcherding, T., W. W. Pommerehne and F. Schneider: Comparing the efficiency of private and public production: evidence from five countries, Zeitschrift fur Nationalokonomie Journal of Economics, Supplement, No. 2, pp,
127-156, 1982.

33) Bhattacharayya, A., E. Parker and K. Raffiee: An examination of the effect of ownership on the relative efficiency of public and private water utilities, Land Economics, Vol. 70, pp. 197209, 1994.

34) Teeples, R. and D. Glyer: Cost of water delivery systems: specification and ownership effects, Review of Economics and Statistics, Vol. 63, pp. 399-408, 1987.

35) Laffont, J.J and J. Tirole: Privatization and incentives, Journal of Law, Economics and Organization, Vol. 7, pp. 84-105, 1993.

36) Laffont, J.J and J. Tirole: A Theory of Incentives in Regulation and Procurement, MIT Press, 1993.

37) Kreps, D.M.: A course in Microeconomic Theory, Princeton University Press, 1990.

38) Schmidt, K. M.: Incomplete contract and privatization, European Economic Review, Vol. 40, pp. 569-579, 1996.

39) Hart, O., A. Shleifer and R. W. Vishny: The proper scope of government: theory and an application to prisons, Quarterly Journal of Economics, Vol. 112, No. 4, pp. 1126-1161, 1997.

40) Shleifer, A.: State versus private ownership, Journal of Economic Perspective, Vol. 12, No. 4, pp. 133-150, 1998.

41) 柳川範之 : 契約と組織の経済理論, 東洋経済新 報社, 2000 .

42) Besley, T. and M. Ghatak: Government versus private ownership of public goods, Quarterly Journal of Economics, Vol. 116, No. 4, 13431372, 2001.

43) King, S. and R. Pitchford: Private or public? A taxonomy of optimal ownership and management regimes, Working Paper of Australian National University, 2001.

44) 大島考介: 不完備契約と PFI, 日本経済研究, No. 43, pp. 87-100, 2001.

45) Hart, O.: Incomplete contracts and public ownership: Remarks, and an application to public-private partnerships, The Economic Journal, Vol. 113, pp. C69-C76, 2003.

46) 三井清 : PFI と内部情報一中途解約と負債によ る規律づけ一, ESRI Discussion Paper Series No.28, 内閣府経済社会総合研究所, 2003.

47）岡本陽介, 大西正光, 坂東弘, 小林潔司 : PFI 事 
業方式における所有権構造と経済的効率性, 都 市計画学会論文集, No.38, pp.175-180, 2003.

48) Francesconi, M. and A. Muthoo: Control rights in public-private partnerships, mimeo, 2006.

49) Klein, B., R. Crawford and A. Alchian: Vertical integration, appropriable rents and the competitive contracting process, Journal of Law and Economics, Vol. 21, pp. 297-326, 1978.

50) Williamson, O.:Economics Institutions of Capitalism, New York: Free Press, 1985.

51) Grossman, S. and O. Hart: The costs and benefits of ownership, A theory of vertical and lateral integration, Journal of Political Economy, Vol.94, pp.691-719, 1986.

52) Kornai, J., Maskin, E. and Roland, G. : Understanding the soft budget constraint, Journal of Economic Literature, Vol., pp.1095-1136, 2003.

53) Hart, O. and J. Moore: Incomplete contract and renegotiation, Econometrica, Vol. 56, pp. 755-785, 1988.

54) Detragiache, E.: Public versus private borrowing: a theory with implication for bankruptcy reform, Journal of Financial Intermediation, Vol.3, pp.327-354, 1994.

55) 大西正光, 石否, 小林潔司 : インフラ PFIにお ける契約保証金と補助金の役割，建設マネジメ ント研究論文集, Vol.12. pp.149-158, 2005.

56 ）石磊, 大西正光, 小林潔司: PFI 事業権契約の効 率性と保証金, 土木学会論文集 D, Vol.62, No.3, pp.383-400, 2006.

57) Hart, O. and J. Moore: Property rights and the nature of the firm, Journal of Political Economy, Vol.98, pp. 1119-1158, 1990.

58) Hart, O.: Firms, Contracts, and Financial Structure, Oxford University Press, 1995.

59) Tirole, J.: The internal organization of government, Oxford Economic Papers, Vol. 46, pp. 1-29, 1994.

60) Francois, P: Public service motivation as an argument for government provision, Journal of Public Economics, Vol. 78, pp. 275-299, 2000.

61) Megginson, W.L. and J.M. Netter: From state to market: a survey of empirical studies on privatization, Journal of Economic Literature, Vol. 39, pp. 321-389, 2001.

62) Boardman, A.E. and A.R. Viking: Ownership and performance in competitive enviroments: a comparison of the performance of private, mixed and state-owned enterprises, Journal of Law and Economics, Vol. 32, pp. 1-33, 1989.

63) Bernheim. D. and M. Whinston: Common agency, Econometrica, Vol. 54, pp. 923-942, 1986.

64) Spiller, P.: Politicians, interest groups, and regulators: a multiple-principals agency theory of regulation (or 'let them be bribed'), Journal of Law and Economics, Vol. 33, pp. 65-101, 1990.

65) Shapiro, C. and R. Willig: Economic rationales for the scope of privatization, in The Political Economy of Public Sector Reform and Privatization, Ezra N. Suleiman and John Waterbury, eds., Westview Press, 1990.

66) Schmidt, K.: The costs and benefits of privatization, Discussion Paper A-330, Princeton University, 1990.

67) ジャン・イブペロ，ゴーティエ シャトリュス:イ ンフラと公共サービスの財政一官民パートナー シップ (PPP) 一, 国際建設技術協会, 2001.

68) Väliä, T.: Economics of Public-Private Partnerships, mimeo, 2005.

69) Aghion, P. and P. Bolton: An Incomplete Contract Approach to Financial Contracting, Review of Economic Studies, Review of Economic Studies, Vol.59, pp.473-494, 1992.

70) 大西正光, 坂東弘, 小林潔司 : PFI事業のため の事業再生手続き, 建設マネジメント研究論文 集, Vol.11, pp.181-192, 2004.

71) Bebchuk, L.: A new approach to corporate reorganizations, Harvard Law Review, Vol.101, pp.775-804, 1988.

72) Aghion, P., Hart, O. and J. Moore: The economics of bankruptcy reform, The Journal of Law, Economics 6 Organization, Vol.8, No.3, pp.523-546, 1992.

73 ) 企業再生実務研究会 : 企業再生の実務, きんざ い, 2002.

74) Holmström, B and J. Tirole: Private and public supply of liquidity, Journal of Political Economy, Vol. 106, No. 1, pp.1-40, 1998.

75) 鈴村興太郎, 長岡貞男, 花崎正晴 : 経済制度の 生成と設計, 東京大学出版社, 2006 . 